\section{Recognizing Famous Faces}

\author{
M. Castillo, Editor-in-Chief
}

The charm of fame is so great that we like every object to which it is attached, even death.

\section{-B. Pascal, French mathematician,} physicist, and philosopher

\section{Part 1: Some Anecdotes}

Johnny Cash. Upon boarding an airplane, I turned around, and there he was-the "Man in Black" (truly dressed in black and carrying a black guitar case). I asked for his autograph and, in the absence of a scrap of paper, had him sign my boarding pass only to have that part immediately taken away by the airline clerk. Seeing what was happening, he again signed the little part of the boarding pass I got back (I still have it, and I bet the airline clerk also has hers).

Mick Jagger. While at dinner at a fancy restaurant in Paris, we noticed that the table closest to us was being prepared again. How could that be when there was only 1 service per table? Well, Sir Mick Jagger walked in accompanied by a beautiful Hispanic-looking woman. I have to report that he was simply dressed, behaved very well, and ate very healthy (no wine, just sparking water and fish, no dessert).

Steve Winwood. As I was having lunch one Saturday, multiGrammy Award winner Steve Winwood walked in and sat beside me. I said, "Hello, Steve," to which he answered by asking me if I had tickets for his concert that night. I lied and said yes. I really do not even like his music.

I have also sat beside Michael Jordan and James Taylor at a local hotel near where I live. Flying back from a meeting, I sat beside the jazz singer Neenah Freelon, who is really as beautiful as she looks on her album covers. I tried to start a conversation but was nervous and could not find anything to say. What is it about fame? Just being in the same room as the famous makes us feel good or even glamorous by association. It never ceases to amuse and entertain me when I go somewhere and people want to meet me because they think I am famous. I may be somewhat famous to some AJNR readers, but that is the extent of my 15 minutes (or perhaps, just my 15 seconds). Are famous individuals that different from you and me?

\section{Part 2: Some Facts}

What makes a person famous? Are the brains of famous people different from those of the rest of us? It is well known that Einstein's brain was removed 7 hours after his death and preserved in formalin. ${ }^{1}$ Its examination showed differences in the parietal operculum, inferior frontal gyrus, and frontal lobe, leading to speculation that because of this, his neuronal connections were faster and more efficient. Histology indicated that some parts of

http://dx.doi.org/10.3174/ajnr.A3100 his brain had more glial cells than those found in controls, but what this really means is uncertain. It is a fact that many wanted a part of his famous brain, a story entertainingly told in Michael Pattertini's book Driving Mr. Albert: A Trip Across America with Einstein's Brain. ${ }^{2}$ Lenin's brain was also removed to gain insight into the genius of communism (American spies tried to get it but were unsuccessful), and it showed a greater-than-average number of pyramidal neurons, which the famous German neuropathologist Oskar Vogt thought accounted for Lenin's greater intellect. ${ }^{3}$ After Vogt's report, the Russians funded the Moscow Brain Research Institute, which houses a collection of their most famous brains (including those of Pavlov and Mendeleev), to study the neuroanatomic basis of exceptional mental capacity and talent. ${ }^{4}$ Data were kept secret until the 1990 and, later when revealed, showed that famous brains had nothing different from yours or mine.

In Japan, at the University of Tokyo, more than 120 brains of famous Japanese prime ministers, novelists, and scholars are kept in a sort of museum and studied to gain insights into what made these individuals who they were. ${ }^{5}$ The Japanese are very respectful of the dead and prefer to keep brains intact rather than cutting them. They have found that these famous brains weigh more than those of common individuals. In the United States, in San Diego at the Department of Radiology of the University of California, one finds the Brain Observatory. ${ }^{6}$ There, more than 1000 donated brains are being studied, the most famous belonging to patient H.M., an individual incapable of forming new memories since neurosurgery for seizures nearly 50 years previously damaged both hippocampi. Other famous institutes housing brains include the Wilder Brain Collection at Cornell University (Dr Wilder was a Civil War surgeon and animal biologist; his collection contains brains of some infamous individuals), the C.U. Ariens Kappers Brain Collection at the Netherlands Institute for Brain Research (it contains mostly animal but also some human brains), and several collections at the Vogt Institut fur Hirnforschung at the University of Dusseldorf in Germany. ${ }^{7}$ When it comes to donating a brain to science, famous individuals as a whole tend to do it more willingly than others. This is probably an extension of their ego and the desire to remain the center of attention even after death. German dramatist, Johann Von Schiller said, "Of all the possessions of this life fame is the noblest; when the body has sunk into the dust the great name still lives."

Because, after all, famous brains are not significantly different from those of common individuals, it is interesting to study how living brains react to fame. It has been postulated that entire brain networks are needed to effectively recognize objects and faces (easier when they are famous). Some studies demonstrate that more than 1 dedicated network is needed for recognition-that is, to recognize a face, visual and vocal networks need to be activated and work together (called dynamic cross-modal networks). ${ }^{9}$ Face recognition depends on intact networks located in the temporal and occipital lobes and anchored by the hippocampi, all working on a parallel basis. Conversely, in 1 study, famous faces elicited a response of only a few neurons located in the medial temporal lobes. ${ }^{10}$ The faces of President Clinton, the Beatles, the Simpsons, 
Jennifer Aniston, and Michael Jordan, among others, were shown to 8 subjects in 21 different sessions. Although all neurons fired when Aniston was shown alone, pictures of her with Brad Pitt resulted in suddenly quiet neurons, an observation difficult to explain. Halle Berry dressed as Catwoman also elicited consistent neuronal firing independent of the subject's sex. Cells that respond to famous human faces have little baseline activity but are turned on rapidly when a familiar face is seen. Thus, some studies suggest that entire neural networks may not be needed for recognition of familiar faces.

It is also amazing how face recognition can erase discrimination. In 1 study, a set of white and black subjects were shown pictures of white and black unknown individuals. With repeated viewing, the brains of whites showed less activity when seeing other whites; the same happened to black subjects but not vice versa. ${ }^{11}$ In a different study, white females were shown faces of white and black individuals (neutral expression and all obtained from old college yearbooks) and were asked to associate these with words. ${ }^{12}$ Black faces elicited a "pro-black bias effect" and were associated with words such as "cancer" and "bomb." The same investigators also performed a similar experiment, but this time showed black faces of famous (not infamous) individuals to the subjects, and amazingly, all negative biases disappeared completely, implying that familiarity (and fame) erased the initial feelings. ${ }^{13}$ Not surprisingly, both articles elicited considerable concern about stereotyping and prejudice and were subject to intense press coverage.

It is also interesting that the more you see a face, the less you use your brain to recognize it. Thus, little effort is needed to recognize the famous (probably explaining why only a few neurons are used). This is particularly true if faces belong to one's own race. The so-called "other race effect" states that as long as the face you are seeing is of your same race, your brain will learn very rapidly to recognize it and will activate less each time you see it, something that takes longer to occur when shown faces of other races. ${ }^{14}$ The opposite is called "cross-race effect"-that is, more effort is needed to recognize faces and expressions of individuals of races other than your own. ${ }^{15}$ The implications of this concept are interesting as we become a more multicultural society. Interestingly, alcohol decreases our ability to recognize familiar faces, and all individuals start looking the same. Therefore, if you get assaulted while intoxicated, even if you recognize the perpetrator in a line-up, your testimony may not hold up in court.

\section{Part 3: More Anecdotes (Other Famous Faces I Have Been Able To Recognize)}

Jack White (of the White Stripes). During a recent trip, I sat in a waiting room at the Detroit airport. Beside me was this guy dressed in black, and upon recognizing him, I said, "Jaackkk Whiiittee!" He looked at me, gave me the smallest of smiles, got up, and walked away. He is taller than I previously thought.

Richard Nixon. As a child, my family and I arrived very late at the Key Biscayne Hotel and Villas for a vacation. The dining room was empty except for the President and his wife, who were eating. My father wanted me to go say hello, but I was too shy to do so. The next year, we arrived late again only to find that there was no space for us in the hotel. We ended up spending the night in Mr Nixon's villa; it was nothing special.

The Boss. With my family, I was having brunch at a restaurant of the Nasher Museum of Duke University during Parents' Weekend when Mr Springsteen walked in (his daughter is a student there). He waited in line nearly 30 minutes for a table, just like us mortals. Mr Springsteen is taller than I thought and looks exactly like he does in pictures. We could not stop staring at him, but because he wore dark sunglasses throughout the meal, we have no idea if he actually saw us doing this.

\section{Part 4: Famous Last Words}

I hope I haven't bored you.

—Elvis Presley, closing remarks during his last press conference

\section{REFERENCES}

1. Albert Einstein's Brain. http://en.wikipedia.org/wiki/Albert_Einstein \%27s_brain. Accessed February 16, 2012

2. Pattertini M. Driving Mr. Albert: A Trip Across America with Einstein's Brain. New York: Dial Press; 2001

3. Oskar Vogt. http://en.wikipedia.org/wiki/Oskar_Vogt. Accessed February 16,2012

4. Vein AA, Maat-Schieman ML. Famous Russian brains: historical attempts to understand intelligence. Brain 2008;131:583-90

5. Kurtenbach E. Famous brains preserved for posterity: research: Japanese scientists hope to gain insight into the mind of great thinkers. Los Angeles Times. January 20, 1991. http://articles.latimes.com/199101-20/news/mn-691_1_famous-brains. Accessed February 16, 2012

6. THE BRAIN OBSERVATORY. http://thebrainobservatory.ucsd.edu. Accessed February 16, 2012

7. Other brain collections. http://brainmuseum.org/explore/other braincoll.html. Accessed February 16, 2012

8. All the Best Quotes. http://chatna.com/theme/fame.htm. Accessed February 16, 2012

9. Joassin F, Psenti M, Maurage P, et al. Cross-modal interactions between human faces and voices involved in person recognition. Cortex 2011;47:367-76

10. Quiroga RQ, Reddy L, Kreiman G, et al. Invariant visual representation by single neurons in the human brain. Nature 2005;435: 1102-07

11. Human kinds in the brain: an MRI scan of racial perception. http:// www.davidberreby.com/human_kinds_in_the_brain__an_mri scan_of_racial_perception_41324.htm. Accessed February 16, 2012

12. Phelps EA, Cannistraci CJ, Cunningham WA. Intact performance on an indirect measure of race bias following amygdala damage. $\mathrm{Neu}$ ropsychologia 2003;41:203-08

13. Phelps EA, O'Connor KJ, Cunningham WA, et al. Performance on indirect measures of race evaluation predicts amygdala activation. J Cog Neuroscience 2000;12:729-38

14. Vizioli L, Rousselet A, Caldara R. Neural repetition suppression to identity is abolished by other-race faces. Proc Natl Acad Sci U S A 2010;107:20081-86

15. Elfenbein, HA, Ambady N. When familiarity breeds accuracy: cultural exposure and facial emotion recognition. J Pers Soc Psychol 2003;85:276-90 